\title{
Jus Cogens Norms in International Space Law
}

\section{Yevgeniya Oralova}

KAZGUU University, Korgalzhyn highway, 8, 010000, Astana, Kazakhstan, LL.M., Senior lecturer at the Chair of International Law and International Relations; eugenia_arenova@mail.ru

\section{Doi:10.5901/mjss.2015.v6n6p421}

\begin{abstract}
This paper is dedicated to the research of the concept of jus cogens norms in international space law. The author is proving existence of the peremptory norms in international space law by the global public interest of the international community in outer space, which occurs first of all because of nature of outer space, its physical characteristics and prospects of exploration and use it gives to States. The author is analyzing opinions of some highly qualified publicists in sphere of international law according to the specific jus cogens norms regulating outer space activities. The theoretical basis of this paper includes studying the scientific researches of such authors as A.D. McNair, A. Cassese, A. Orakhelashvili, R. Jakhu. This paper also includes researching legal nature of some of jus cogens norms in international space law, in particularly, the principle of nonappropriation of outer space and the principle of freedom of exploration and use of outer space for the benefit of all States.
\end{abstract}

Keywords: Jus cogens norms, peremptory norms, international space law, principles, outer space, non-appropriation, erga omnes obligations.

\section{Introduction}

The concept of jus cogens norms has occurred in the positive international law recently and since then it has been covered by the mist of uncertainty. The International Law Commission, while developing the Vienna Convention on the Law of Treaties of 1969, where this concept has been put into action, tried to avoid the defining of the complete list of such norms very diplomatically, having mentioned the prohibition of use of force and threat of use of force, prohibition of genocide and piracy and some others. The Commission has specified that the full content of the article dedicated to the jus cogens norms has to be developed by States and international courts practices (Yearbook of the ILC, 1966, Vol. II). But both States and judicial authorities use this concept very carefully and unwillingly and avoid classifying norms as peremptory ones. Jus cogens norms practice in the international space law is out of the question at all. However, according to the fair remark of Alexander Orakhelashvili the absence of practice and refusal of justice to make references to the legal principle do not mean that this principle does not exist (Orakhelashvili, 2009). We should agree with this remark and in my opinion this excessive myphologization of the jus cogens norms negatively affects the progress of international legal doctrine and the system of international law itself.

It is important to note that a lot of research papers and other scientific teachings are dedicated to study of the concept of jus cogens norms, as well as its elements and effects. There are publicists, who are sure that peremptory norms exist in international space law, among them are Ram Jakhu, Cestmir Cepelka and Jamie H.C. Gilmour. At the same time, no learned treatise which includes exact rationale and proves of existence of jus cogens norms in the international space law has been found while preparing this paper.

Being convinced, that existence of jus cogens peremptory norms is natural for international legal order, I would like to dedicate this paper to the investigation of jus cogens norms concept in the field of space activities. The primary objective of this paper is to prove the existence of jus cogens norms in international space law. Another objective is to examine the legal nature of peremptory norms governing space activities.

\section{Methodology of the Research}

The methodology plays a significant role in the scientific research. Scientific research methodology as the study of the organization of scientific activity allows not only to get new knowledge, but also to organize it. The main method used in the present paper is a method of legal analysis allows us to consider the different sides and characteristics of the research object separately and examine the issue more detailed. This method has been used primarily in exploring the legal nature of a peremptory norm in international space law, in particular in studying its elements. The one of the most 
important methods that has been used in the research is a legalistic approach. This method is required to examine and interpret the content of specific norms, including those that govern space activities. The simulation approach is also should be mentioned as the part of research methodology as it allows to simulate the hypothetical situation or legal problem and show how the specific regulation will operate in these conditions. This approach is used in the part of the paper dedicated to the effect of jus cogens norms in international space law.

\section{Statements of Necessity of Jus Cogens Norms in International Space Law}

According to specialists, origin and existence of international legal order norms, which have higher rank, or peremptory norms, how we used to call them, is connected with different concepts and categories. In Arnold D. McNair's view international norms "which stand in a higher category and which can not be aside or modified by contracting States" are necessary "to protect the public interests of the society of States or to maintain the standards of public morality recognized by them"(McNair, 1961). As a result, McNair connects existence of peremptory norms with such categories as "public interest" and "public morality". Igor Lukashuk mentions that when the International Law Commission started to develop the concept of peremptory norms, it has been connected with the concept of public policy, which can be understood as a "complex of principles of community organization, which are necessary for its existence and development" (Lukashuk, 2008). It is also essential to mention the opinion of Yelena Trikoz, who is connecting jus cogens norms with such category as the "legitimacy of international law", which is based on the principle of rule of international law including also "obligation of its regulations and incontestable authority of norms, presented as peremptory ones (jus cogens)" (Trikoz, 2006). She also specifies that peremptory norms particularly "strengthen the subordinated hierarchic ties and limit freedom of execution of Treaties within the law" (Trikoz, 2006). According to ex-member of the United Nations International Law Commission dr. Andreas Jacovides "rules of jus cogens do not exist in order to satisfy the needs of individual States but in order to serve the higher interests of the international community as a whole" (Outlines prepared by members of the Commission on Selected topics of international law, Extract from the Yearbook of the ILC: 1993, vol. II). In his major work "Peremptory norms in international law" Orakhelashvili also mentions that "jus cogens norms embody a transcendent common good of the international community" and their purpose is to protect interests and values which are common for all States and other subjects of international relations (Orakhelashvili, 2009). Despite the fact, that presented opinions are characterized by different categories and notions, which are used to define jus cogens norms, all above-mentioned authors agree that peremptory norms serve the purpose and protect legal interests, which are common for the members of international community and are required to maintain international legal order.

I suppose that existence of international legal system is not possible with the absence of peremptory norms, derogation of which is not permitted. In my opinion the presence of peremptory norms in international law makes international legal order integral and cohesive and turns international law into a particular system of law. Otherwise, international law would not be able to claim the criterion of systematic, staying a set of fragmented norms and rules and separated legal regimes.

Based on the thesis that international law is a particular and self-contained system of law, I am absolutely sure that in international law just like in any other system of law have formed and are still forming so-called branches, such as international space law.

These branches regulate different fields of international relations, they are also systematic and integral, which means they also have jus cogens norms. International space law being one of the branches of international law needs peremptory norms, including some specific ones, peculiar for the sphere of international relations it is served to control and regulate.

Common interest of members of international community has been defined as a category, which proves the presence of peremptory norms in international law. The question arises if this common interest exists in the field of outer space activities and how we can prove the necessity of peremptory norms in international space law.

To answer this question there is a need to take a look at the Treaty on Principles Governing the Activities of States in the Exploration and Use of Outer Space, including the Moon and Other Celestial Bodies adopted by resolution 2222 (XXII) of the UN General Assembly on the 19th of December, 1966 (hereinafter - the Outer Space Treaty). According to its preliminary statement the States Parties to this Treaty have agreed on it "recognizing the common interest of all mankind in the progress of the exploration and use of outer space for peaceful purposes" and "believing that the exploration and use of outer space should be carried on for the benefit of all peoples irrespective of the degree of their economic or scientific development". Article I of the Outer Space Treaty develops this idea and defines that "the exploration and use of outer space, including the Moon and other celestial bodies, $<\ldots>$ shall be the province of all mankind" (Outer Space Treaty). This means that such concepts as "common interest", "benefit of all peoples", and 
"province of all mankind" are mentioned in the Outer Space Treaty. The use of these terms in the Treaty confirms my thesis that there is a common interest of international community to set and maintain regime of outer space. These notions we can use to build on proving the concept of jus cogens norms in international space law.

This idea is supported by the opinion of famous expert in international space law Ram Jakhu. He proves the existence of so-called global public interest in outer space also is referring to the Outer Space Treaty. R. Jakhu in one of his works mentions that "the legal principles of current international space law, especially the Outer Space Treaty, recognize the inclusive interest of the international community - that is, the global public interest - in outer space by assuring all States the right of free access to outer space without discrimination of any kind" (Jakhu, 2006).

What is the reason of existence of this "global public interest" in outer space? I think, that interest of global community in exploration and use of space is connected, first of all, with the nature of outer space and the prospects which open up before the global community in the spheres of TV and radio service, mobile telecommunication and navigation, meteorological observation, remote sensing of ground surface for strategic and self-defensive purposes and many other kinds of human activities. Moreover, the exploration of outer space has started recently, and there are still a lot of unknown things. Its physical characteristics make any space activities connected with risks and potentially dangerous for the people. This is the reason of "global public interest" not only in outer space, but in establishment of the rules of its exploration and use, which would become obligatory and, moreover, peremptory for all the members of international community in order to maintain stability of outer space legal regime.

\section{Norms and Principles in International Space Law Claiming the Peremptory Nature}

As I have mentioned in the Introduction of this paper some authors suppose that several norms of the Outer Space Treaty have peremptory nature (Brisibe, 2009). For instance, R. Abeyratne notices that the obligation mentioned in the Article I of the Outer Space Treaty is the peremptory norm of international law jus cogens (Abeyratne, 2011). Some other specialists also held to an opinion that the principle of non-appropriation of outer space has the legal nature of jus cogens norm (Kayser, 2001; Lee, 2012).

According to R.Jakhu four important principles, such as principle of exploration and use of outer space for the benefits of all peoples, principle of freedom of exploration and use of outer space (Article I), principle of outer space not being a subject to national appropriation (Article II), principle of regard to the interests of all other States during any activities in outer space (Article IX), fixed in the Outer Space Treaty and presented elements of "global public interest" are jus cogens norms (Jakhu, 2006).

C. Cepelka and H.C. Gilmour mention not only separate norms of international space law which have peremptory nature, specialists point at the presence of the groups of jus cogens norms which establish international legal regime of outer space. According to them the first group of jus cogens norms is headed by the above-mentioned principle of nonappropriation of outer space, including celestial bodies. This group also includes prohibition of exclusive jurisdiction establishment and principle of free access to outer space and celestial bodies (Cepelka and Gilmour, 1970).

The second group includes the restriction of natural resources use in outer space with due regard to interests and benefits of global community. Ban of use of force or threat of force, including right to self-defense, which according to the authors is reflected in the Article III of the Outer Space Treaty, is included to the third group of jus cogens norms applied in international space law. And the last group of jus cogens norms in international space law are the "considerations of humanity", which oblige States to rescue astronauts regardless of their citizenship. C. Cepelka and H.C. Gilmour also mention that these norms can not be changed in accordance with the Article XV of the Outer Space Treaty and ignored even by States, which decide to withdraw from the Treaty (Cepelka and Gilmour, 1970).

In the monograph "Correlation of international and domestic law: theory, practice and methods of teaching" Z.Matchanova mentions that principle of peaceful use of outer space should be regarded as the jus cogens norm in international space law (Matchanova, 2009). This opinion could be argued, because we all know that the outer space is only partially demilitarized (the Article IV of the Outer Space Treaty states that only the Moon and other celestial bodies shall be used exclusively for peaceful purposes, but we can not say the same about the other parts of outer space). Moreover, we know for sure that outer space is not used only for peaceful purposes, first of all if we speak about remote sensing of the Earth and use of the received data for military strategic purposes.

However, I suppose that we should not ignore provision of the Article IV of the Outer Space Treaty as the potential jus cogens norms. In my point of view, ban of place in orbit around the Earth any objects carrying nuclear weapons or any other kinds of weapons of mass destruction, install such objects on celestial bodies or station such weapons in outer space is totally an peremptory norm in international space law.

Trying to define potential jus cogens norms in international space law I have to mention official position of 
Venezuela in this regard. According to the position of Bolivarian Republic of Venezuela which is given as an answer to the United Nations Committee on Peaceful Use of Outer Space question about differences between legal regimes of air space and outer space, the last one is a common heritage of the mankind "by virtue of jus cogens norms" (Questionnaire on possible legal issues with regard to aerospace objects: replies from Member States, 2007).

This means that Venezuela is sure that jus cogens norms exist in the international space law and define special legal regime of exploration and use of outer space. All the above-mentioned data allows us to note that the list of potential jus cogens norms in international space law is impressive. But how can we define if one or another norm is jus cogens with all that it implies? I suppose that we should look for the answer in the legal nature of peremptory norms. That is what the next part of this article is about.

\section{Legal Nature of Jus Cogens Norms in International Space Law}

To understand the legal nature of jus cogens norms in international space law we have to, first of all, define what is the source of such norms, how do they form and why the derogation is not permitted. In our point of view, the legal effect of such norms is also a very important element of jus cogens norms legal nature.

\subsection{The sources of jus cogens norms in international space law}

Without depreciating the importance of international treaties, which codify customary rules, or are a base for the following emergence of custom, I agree with the statement that peremptory norms in all cases have customary legal nature, because international custom is the only source of general international law, which creates the obligations for all members of international community no matter if they are parties of any treaties or not. The idea that jus cogens norm can not be created by a treaty, although the treaty can take part in origin of such norms has been expressed on the $877^{\text {th }}$ meeting of the International Law Commission (Summary record of the 877th meeting. Extract from the Yearbook of the International Law Commission, 1967), this proves the above-mentioned opinion. If we look at the first part of definition of peremptory norm which is embodied in the Vienna Convention of 1969, which says that jus cogens norm is a norm accepted and recognized by "the international community of States as a whole" (Vienna Convention on the Law of Treaties, art.53), we will see the similarity to development of customary norm, where one of the elements is "general practice" (Statute of the ICJ, art.36). In my view, this similarity proves again that jus cogens norm always has a simple legal nature.

The custom is of key importance in international space law. According to some specialists, norms which are fixed in the Outer Space Treaty reflect customary international law. For instance, W.G.Witztum mentions freedom of exploration and use of outer space, ban of national appropriation of outer space, preservation of state sovereignty with respect to astronauts and objects launched into outer space. He also notices that these norms have been formed as customary ones even before the entry Outer Space Treaty into the force (Witztum, 2011). In reference with the above we should not forget the resolution of the UN General Assembly of 1962 (XVIII), which is called the "Declaration of Legal Principles Governing the Activities of States in the Exploration and Use of Outer Space".

This resolution contained principles, which have been fixed in the Outer Space Treaty and was adopted unanimously. During the adoption of the resolution the representative of the US said that its principles of space activities reflect "international law as it is recognized by members of the UN". It should be noted that other delegations supported the opinion of the US and noticed that the Declaration was "a codification of key rules of customary international law, regulating outer space activities" (Scharf, 2013). This means that the norms fixed in the Declaration and the Outer Space Treaty and mentioned in the previous part of this article are potential source of jus cogens norms in international space law.

\subsection{Elements of jus cogens norms in the context of international space law}

The concept of peremptory norms existed in international law before the Vienna Convention on the Law of Treaties was adopted in 1969. But this Convention made the concept integral and complete, it let speak about normative consolidation of the idea of peremptory norms. Article 53 of the Vienna Convention contains the definition of the jus cogens norm, which consists of several elements. According to this Article "peremptory norm of general international law is a norm accepted and recognized by the international community of States as a whole as a norm from which no derogation is permitted and which can be modified only by a subsequent norm of general international law having the same character" (Vienna Convention on the Law of Treaties, art.53). On the basis of this definition the following elements of jus cogens 
norms are identified: 1) acceptance and recognition of the jus cogens norm are accomplished by the international community "as a whole"; 2) no derogation is permitted; 3) such norm can be modified only by a subsequent norm of general international law having the same character.

Obviously, first two elements are particularly important, and I would like to study and analyze them in the context of space activities and international space law. With relation to the limits of the size of the article, only non-appropriation of outer space and freedom of exploration and use of outer space as core principles of international space law can be analyzed in details.

Coming back to the first principle we have to understand what does the international community of States "as a whole" means. Does it mean that each and every State has to recognize the norm as jus cogens one to make it become legal status? To answer this question Antonio Cassese quotes the extract from the official record of the $1^{\text {st }}$ Session of the UN Conference on the Law of Treaties in 1968, according to which the term "as a whole" does not mean that the norm has to be accepted and recognized as peremptory by all States, but "a very large majority" of the States is enough.

Moreover, if one state or a small number of states refuses to accept the peremptory character of the norm then it would not affect the acceptance and recognition by the international community as a whole (Cassese, 2002).

In respect of the principle of non-appropriation of outer space we should mention the Bogota Declaration of 1976, where eight equatorial countries claimed their sovereign rights on the segments of geostationary orbit that corresponds to their national territories (Declaration of the First Meeting of Equatorial Countries (the Bogotá Declaration). I suppose, that claim of such small group of states can not be regarded as a preclusion for the principle of outer space non-appropriation to be recognized as jus cogens norm. This idea is supported by the opinion of Ricky Lee, the author of "Law and Regulation of Commercial Mining of Minerals in Outer Space". According to him, even if we regard this group of states as an "important element of international community", approval of which we need for acceptance and recognition of jus cogens norm, the fact that two states from this group (Brazil and Ecuador) ratified the Outer Space Treaty, two states (Kenya and Uganda) joined this Treaty and three countries (Columbia, Indonesia and the Democratic Republic of Congo) have signed it, puts in question absence of this approval (Lee, 2012).

Cassese also mentions that "a peremptory norm can only take shape if the most important and representative States from the various areas of the world consent to it" (Cassese, 2002). Here rises an appropriate question, how we define whether the state is "the most important and representative" or not and is it possible to regard the states as more or less important according to the principle of sovereign equality of the states. I can agree with the opinion of Cassese only partially, if we regard the state according to the degree of its involvement into the sphere of international relations, where the jus cogens norm is forming. If we speak about jus cogens norm in international space law, then its acceptance and recognition will not be possible without approval of so-called "space powers", i.e. the states which are involved into an active space activity. Moreover, it does not need to be accepted in an active way (through discussion, negotiation or statement), but can be expressed in passive acceptance, i.e. tacit agreement with such norm.

To study the second element in the context of international space law it necessary to understand why no derogation from jus cogens norm is permitted or why such norm cannot be eliminated by agreement of two or more states. In my opinion, one of the reasons is that the natural order of international law will be disturbed in this case. In this connection, I should mention the view of A. Orakhelashvili. In his book he analyzes a very interesting idea that the concept of jus cogens peremptory norms "has its roots in the natural law doctrine of classical international law". Orakhelashvili notices that "this natural law of nations is necessary, because Nations are absolutely bound to observe it. Such law "is not subject to change" by agreement of states or unilaterally" (Orakhelashvili, 2009).

Nature of jus cogens norms in international space law fits perfectly in the pattern of this concept. Above-mentioned norms, first of all, non-appropriation of outer space should be regarded with no derogation permitted, because they meet the outer space state of nature, its physical characteristics, define its regime and create conditions for its safe exploration and use.

The recognition of outer space as a "province of all mankind", which is explained by its nature, is a base of the principle of non-appropriation of outer space. This thesis is supported by the idea of the British legal expert B.Jenks. According to him, the nature of outer space eliminates the possibility of its national appropriation (Brownlie, 1973). By contrast with earth surface or air space, which have their limits, outer space is infinite and any attempts to appropriate it or divide it among states would be difficult and, what is more important, could have led to the conflicts between states which wanted to get a bigger part. As a result it would negatively affect the possibilities of space exploration and use of its huge potential, and progress in science and technology, which is unthinkable without outer space. Consequently, derogation from norms, which define outer space as unliable for national appropriation and free for exploration and use of outer space for benefits of all States is not permitted, because they support regime, created also for maintenance of international peace and security. 


\subsection{The effect of jus cogens norms in the context of international space law}

In accordance with the Article 53 of the Vienna Convention on the Law of Treaties of 1969 "a treaty is void, if at the time of its conclusion, it conflicts with a peremptory norm of general international law" (Vienna Convention on the Law of Treaties, art.53). It means that such treaty does not create any rights or legal obligations and does not create legal consequences. I suppose that this effect of jus cogens norms is valid not only for the treaties, but also for other legal acts, which aim is to create legal obligations and consequences in international law. In this connection I should mention again the Bogota Declaration of 1976. In the official documents of the Committee on the Peaceful Uses of Outer Space is mentioned that the claims on sovereign rights on the segments of geostationary orbit of eight equatorial States have been rejected as "contradictory to the fundamental principle of international space law of non-appropriation of outer space" (Matters relating to the definition and delimitation of outer space. Committee on the Peaceful Uses of Outer Space , Legal Subcommittee Fifty-third session). Of course, it is not directly mentioned in that document, that the Declaration is contrary to the peremptory norm, but the fact that the claims of equatorial States have been rejected as contradictory to this principle suggests us some sort of thinking about its legal nature and peremptory character.

It should be mentioned, that one of the legal effects of jus cogens norms is that it creates erga omnes obligations, i.e. the obligations of the international community as a whole (Lukashuk, 2008). The concept of erga omnes obligations for the first time reflected in the judgment of the United Nations International Court of Justice on the case concerning "Barcelona Traction" Company (Belgium v. Spain).

It is said in the judgment of the International Court of Justice that "an essential distinction should be drawn between the obligations of a State towards the international community as a whole, and those arising vis-à-vis another State in the field of diplomatic protection". The first type of obligations has been defined by the International Court of Justice as erga omnes obligations. The Court also defined that obligations toward the international community as a whole are concern of all States by the nature and have to be held "to have a legal interest in their protection" (Barcelona Traction Case). As we can see the legal interest is the basis of the legal nature of jus cogens peremptory norms and erga omnes obligations, and it is common for the international community as a whole and for each member separately. The presence of this interest creates an inextricable connection between these two concepts - jus cogens norms and erga omnes obligations.

This consequence relates to the question of responsibilities under international law. For instance, Articles on responsibilities of a State for its international wrongful acts of the Resolution adopted by the United Nations General Assembly 56/589 12 December 2001 differ the situation when the responsibility is invoked by an injured State or a State other than an injured. According to paragraph $b$ of Article 48 any State other than an injured State is entitled to invoke the responsibility of the other State if "the obligation breached is owed to the international community as a whole" (Responsibilities of States for Internationally Wrongful Acts). As a result, regarding the principle of non-appropriation of outer space and inseparably associated principle of exploration and use of outer space for the benefit of all States as jus cogens norms, we should remember that any attempt to defy these principles any State should be regarded as having a legal interest in their protection and invocation of responsibility of the offending State.

In this connection there is interesting news that some US private "Bigelow" company is trying to obtain a permit from the US government to build the base on the Moon and to have exclusive rights on the use of this base, what also supposes having exclusive rights on the part of the territory of the Moon (Clotz, 2015). We assume that if the US government approves this, it will be a serious breach of principles of non-appropriation of outer space and freedom of exploration and use of outer space for the benefits of all states. I suppose, that it will cause massive outcry in the international community, and any state will be able to declare a protest concerning the US approval as assaulting the common interest of the international community and the "province of all mankind".

\section{Conclusion}

This research allows me to draw some conclusions about the origin and existence of jus cogens norms in international space law. First of all, I should notice that the existence of jus cogens norms in international space law is not a myth, but an objective reality. No fewer than two main and closely connected principles - of non-appropriation of outer space and of freedom of exploration and use of outer space should be regarded as jus cogens norms in accordance with the "global public interest", which they protect and guarantee. This interest is defined, first of all, by the nature of outer space and its physical characteristics, and the prospects which open up before the global community in the fields of its exploration and use.

Potential derogation from the principles of non-appropriation of outer space and of freedom of exploration and use 
of outer space, which are essential for the whole system of international space law is inconsistent with the natural state of outer space and can threaten international space and security. These activities should be regarded as a breach of obligations toward international community as a whole (erga omnes obligations) and invasion of "global public interest" and "province of all mankind". Any state is entitled to claim a protest against such activities and to invoke the responsibility of the offending state.

At the same time this research is not exhaustive and finished, but it opens possibilities for the following surveying of the existence of jus cogens norms in international space law.

\section{References}

Abeyratne, R. (2011). Space security law. Heidelberg: Springer.

Brisibe, T. (2009). Customary International Law, Arms Control and the Environment in Outer Space. Chinese Journal of International Law, 8(2), 375-393. doi:10.1093/chinesejil/jmp009

Brownlie, I. (1973). Principles of public international law. 2. ed. Oxford: Clarendon Press.

Case Concerning the Barcelona Traction, Light and Power Company, Limited (Belgium v. Spain), Judgment of 5 February 1970. [Online] Available: www.icj-cij.org/docket/files/50/5387.pdf_(July 14, 2015).

Cassese, A. (2005). International law (2nd ed.). Oxford: Oxford University Press.

Cepelka, C. \& Gilmour J.H.C. (1970). The Application of General International Law in Outer Space. The Journal of Air Law \& Commerce, 36, 30-49.

Clotz I. Exclusive - The FAA: regulating business on the moon. [Online] Available: www.reuters.com/article/2015/02/03/us-usa-moonbusiness-idUSKBNOL715F20150203_(June 22, 2015).

Declaration of the First Meeting of Equatorial Countries (the Bogotá Declaration). [Online] Available: http://www.jaxa.jp/library/ space_law/chapter_2/2-2-1-2_e.html (June 22, 2015).

Jakhu, R. (2006). Legal Issues Relating to the Global Public Interest in Outer Space. Journal of Space Law, 32(1), 31-110.

Kayser, V. (2001). Launching space objects: Issues of liability and future prospects. Boston: Kluwer Academic.

Lee, R. (2012). Law and regulation of commercial mining of minerals in outer space. Dordrecht: Springer.

Lukashuk, I. (2008). International Law. Common Part (3d ed.). Moscow: Wolters Kluwer.

Matchanova, Z. (2009). Determining norms jus cogens in the Vienna Convention on the Law of Treaties of 1969. In Correlation of international and domestic law: theory, practice and methods of teaching (pp.141-143). Saint-Petersburg: Litres.

McNair, A. (1961). The law of treaties. Oxford: Clarendon Press.

Orakhelashvili, A. (2009). Peremptory norms in international law. Oxford: Oxford University Press.

Scharf, M. (2013). Customary international law in times of fundamental change: Recognizing Grotian moments. Cambridge: Cambridge University Press.

Statute of the International Court of Justice. [Online] Available: http://www.icj-cij.org/documents/?p1=4\&p2=2 (July 14, 2015).

Trikoz, Y. (2006) International Legality (to the problem). International Public and Private Law, 5, 7-11.

United Nations, 1967. Summary record of the 877th meeting. Yearbook of the International Law Commission 1966, Vol. I (2), United Nations, New York.

United Nations, 1967. Yearbook of the International Law Comission 1966, Vol. II, United Nations, New York.

United Nations, 1967. Treaty on Principles Governing Activities of States in Exploration and Use of Outer Space, 8843 Treaty Series 610, New York.

United Nations, 1987. Vienna Convention on the Law of Treaties, 18232 Treaty Series 1155, New York.

United Nations, 1995. Outlines prepared by members of the Commission on Selected topics of international law. Yearbook of the International Law Commission 1993, Vol. II, United Nations Press, New York and Geneva.

United Nations, 2001. Responsibilities of States for Internationally Wrongful Acts, GA Res 56/83, Dec 12, 2001. [Online] Available: daccess-dds-ny.un.org/doc/UNDOC/GEN/N01/477/99/PDF/N0147799.pdf?OpenElement_(June 22, 2015).

United Nations, 2007. Questionnaire on possible legal issues with regard to aerospace objects: replies from Member States. Committee on the Peaceful Uses of Outer Space. [Online] Available: http://www.unoosa.org/pdf/reports/ac105/AC105_635Add14E.pdf (July 14, 2015).

United Nations, 2014. Matters relating to the definition and delimitation of outer space. Committee on the Peaceful Uses of Outer Space, Legal Subcommittee Fifty-third session. [Online] Available: http://www.unoosa.org/pdf/limited/c2/AC105_C2_2014_DEF_L01E. pdf (July 14, 2015).

Witztum, W.G. (2011). International Law = Volkerrecht. Infotropic Media. 